\title{
Reducing Anxiety and Shyness for Oral Interaction Improvement in a Cooperative Learning Environment ${ }^{1}$
}

\section{Reduciendo la ansiedad y la timidez para mejorar la interacción oral en inglés dentro de un entorno de aprendizaje cooperativo}

\author{
Jorge Orlando Robayo Guerrero ${ }^{2}$ \\ jorlandor56@yahoo.com \\ Universidad de Cundinamarca - Ubaté, Colombia
}

Received: September 5, 2015

Accepted: December 7, 2015

How to cite this article (APA, 6th ed.): Robayo, G. (2016) Reducing Anxiety and Shyness for Oral Interaction Improvement in a Cooperative Learning Environment. Enletawa Journal, 9 (1), $53-65$.

\section{Abstract}

This article reports on the investigation carried out at rural school in Ubate (Cundinamarca). Participants were sixteen English students. The aim of the study was to explore how cooperative learning reduces ninth graders' anxiety and shyness in the English classes. In order to achieve this objective, an action research study was conducted. Interviews, teacher's diary and workshops were used for data collection. The main findings suggested that after five workshops anxiety and shyness' signs have reduced when students were cooperative to interact orally. In addition, cooperative learning was an effective tool not just to reduce anxiety and

1 This paper shows the research progress of a project dealing with cooperative learning approach to minimize students' shyness and anxiety.

2 He holds a B. A. in Modern Languages English- French from Universidad Pedagógica Nacional. He is currently a M.A. in Language Teaching candidate at UPTC. He is a full-time Professor at Universidad de Cundinamarca. 
shyness, but also to involve them in their own English learning process, English learning

Key words: Anxiety, Shyness, Cooperative Learning, English Learning.

\section{Resumen}

Este artículo da cuenta de la investigación desarrollada en un colegio rural en Ubaté (Cundinamarca). Los participantes fueron dieciséis estudiantes de la clase de inglés. El objetivo fue explorar cómo el aprendizaje cooperativo reducía la ansiedad y la timidez en las clases de inglés con el grado noveno. Para lograr este objetivo, se desarrolló una investigación-acción. Para la recolección de los datos se utilizaron entrevistas, diario del profesor y talleres. Las conclusiones sugieren que después de haber aplicado cinco talleres, los signos de ansiedad y timidez se han reducido en las interacciones orales de los estudiantes. También, que el aprendizaje cooperativo no solo fue una herramienta efectiva que ayudó a reducir la ansiedad y la timidez, sino que involucró a los estudiantes en su propio proceso de aprendizaje del inglés.

Palabras claves: Ansiedad, Timidez, Aprendizaje Cooperativo, Aprendizaje de inglés. 


\section{Introduction}

The cooperative learning teaching experience with ninth graders at "San Francisco de Asís" rural school (UbatéCundinamarca) has shown that one of the most relevant factors in the learning and teaching process is the affective one. Affection is involved in all human beings' activities, and it is related to motivation, tolerance, self-esteem, anxiety and shyness among others; those aspects contribute to determine student academic success or failure.

This paper explores theimprovement of two related affect dimensions: anxiety and shyness, in order to identify how a cooperative learning approach can reduce both anxiety and shyness in ninth graders' oral interaction. Initially, this investigation began with the idea of improving English class students' interaction in a private school, especially in oral presentations because we observed that students showed some kind of behaviors that drastically affect their success oral classroom performance.

In this sense, through continuous observation, it was determined that students seemed to be anxious and shy in many oral activities, for instance, in role-plays activities, small oral presentations, informal conversations, common oral interaction, answering questions, among others. Besides, students showed some sign of shyness such as a lack of interest producing oral reports or answering simple questions; and in regards to anxiety, students engaged in some actions such as rolling their pen or fingers into their hair, trying to call the attention all the time by screaming, laughing and joking.

After identifying these students' attitudes when they were doing any form of oral presentation, the next step was to observe and analyze those attitudes in order to look for possible solutions by means of cooperative learning activities to minimize anxiety and shyness. At the same time, the study sought to promote positive attitudes depending on students' needs to make them feel comfortable and confident in real-life oral interaction. Bearing the previous in mind, the question this paper set to answer in the following pages is: how does a cooperative learning approach reduce anxiety and shyness-related factors in order to improve students' English oral interaction at "San Francisco de Asís" rural school (Ubaté-Cundinamarca)?

\section{Literature Review}

This section describes the main constructs that support the ideas in the present article. It starts with a revision of cognitive development theory: Piaget and Vygotsky; then, anxiety and shyness into learning process; it follows with communicative competence; cooperative learning and oral interaction. 


\section{Cognitive Development Theory:}

\section{Piaget and Vygotsky.}

On one hand, Piaget's idea was based on children learn through action, meaning that children are born with and acquire schemas; these schemas could be concepts about how to act and respond to the world. As children explore their world, they form and reform ideas in their minds. The more actively involved children are the more knowledge is gained. On the other hand, Vygotsky's focused on the role of culture and social interactions in learning. In other words, that students learn through social interactions and their culture, through what Vygotsky called dialogues. Through these dialogues, we socially interact and communicate with others to learn society's cultural values.

\section{Piaget's Assertions.}

Piaget showed that children think in strikingly different ways from how adults do. Also, he suggested that children were born with a very basic mental structure upon which all subsequent learning and knowledge is based on. The goal of this theory is to explain the mechanisms and processes in order to reason and think using hypothesis. Piaget thought it was necessary that children move through an adaptation process, which is related to the individual's aptitude for understanding her or his. In this way, individuals construct their comprehension of the world around them; they experience discrepancies among what they know and what they discover in their environment.

Into his theory, Piaget talked about schemas, assimilation and accommodation, and stage of cognitive development. This study has considered authors such as (Dimitriadis and Kamberelis, 2006; Siegler and Opfer, 2003; Campbell, 2006; Agnes, 1999) because they focus on assimilation, accommodation and equilibrium in the adaptation process.

According to Dimitriadis and Kamberelis (2006), assimilation takes place when children's old knowledge (existing mental scheme) is combined with new information. Assimilation is "when a child has seen something before and applies that to current situation" (Siegler, 2003). Accommodation occurs when the knowledge (existing schema) does not work and needs to be changed to deal with a new object or situation.

Finally, according to Piaget, quoted by Agnes (1999, p. 1282), equilibrium is the balance between assimilation and accommodation. Piaget thought that children feel that balance when they have established the relation between psychological schemas (knowledge) and the real world.

Piaget states that social interaction support infants understanding of the world around them. Piaget (1959) defined social interaction as interchange of ideas among people in order to construct knowledge; then, individuals 
incorporate interchange of ideas in their schemata. Schemata becomes new ideas that are incorporated, so, the schemata fits as new knowledge.

\section{Vygotsky's Assertions.}

Vygotsky focused on the role of culture and social interactions. He stated that students learn through social interactions and their culture. Through "dialogues" we socially interact and communicate with others to learn the cultural values of our society. Moreover, he believed that "human activities take place in cultural settings and cannot be understood apart from these settings" (Woolfolk, 2004, p. 45). Social interaction allows students to learn together. According to Fogarty (1999, p. 77), "Vygotsky suggests that we learn first through person-to-person interactions and then individually through an internalization process that leads to deep understanding".

A key concept in Vygotsky's (1978) sociocultural theory is the "zone of proximal development (ZPD)". It is related to difference between what a child can accomplish by himself and what a child can accomplish with a skilled partner's support. This scholar observed that interaction with peers was an effective way of developing skills and strategies. Thus, it is suggested that teachers use cooperative learning exercises so that children with a lesser degree of ability or less knowledge are supported by more skillful peers as they together work in their learning.

\section{Anxiety and Shyness in the Learning Process.}

Each life stage has its own characteristics and displays some factors that affect students' English oral interaction. According to Brown (2007) “Teens are ultrasensitive to how other perceives their changing physical and emotional selves along with their mental capabilities" (p. 92). Learning a language is related to emotions in a way other subjects do not. Guiora, Brannon and Dull (1972), Horwitz (1984), Lybeck (2002) explain that "Language" is at the same time: a) A communication coding system that can be taught as a school subject. b) An integral part of the individual's identity involved in almost all mental activities. c) The most important channel of social organization embedded in the culture of the community where it is used.

On the other hand, Gardner (1985) affirms that teachers need to take into account the context, culture, and individual because each one has different backgrounds and conceive the acquisition of other language with diverse points of view; these differences have a great influence on the individual. Gardner also states that other valuable variable for learning a second language is motivation that defines as "the extent to which the individual works or strives to learn the language because of a desire to do so and the satisfaction experienced in this activity, (Gardner, 1985, p. 6). 
Many authors have made an approximation of anxiety and shyness concepts. Gardner and MacIntyre (1993) defined anxiety as "the apprehension experienced when a situation requires the use of a second language with which the individual is not fully proficient" (p.163). Spielberger (1983) affirms that anxiety is "the subjective feeling of tension, apprehension, nervousness, ad worry associated with an arousal of the autonomic nervous system" (p.1). Scovel (1978) points out that anxiety is associated with feelings of uneasiness, frustration, self-doubt, apprehension, or worry (p. 134). There are correlations between anxiety and performance.

\section{Cooperative Learning.}

Cooperative learning is related to how students can work together. In cooperative learning models, a group learning activity depends on structured exchange of information between learners. According to Slavin (1964), quoted by D'Olivares (2013, p. 61), cooperative learning has the potential to take advantage of "the developmental characteristics of adolescents in order to harness their peer orientation, enthusiasm, activity, and craving for independence within a safe structure".

Johnson and Johnson (1995) and Brandt and Ellsworth (1996) discuss five necessary factors for successful cooperative learning, which are also presented in collaborative environments: a. Positive interdependence, a sense of working together for a common goal and caring about each other learning.

b. Individual accountability, personal contributions to the team.

c. Abundant verbal, face-to-face interactions, when learners explain, argue, elaborate, construct and link previous with new knowledge.

d. Sufficient social skills, involving explicit teaching of appropriate leadership.

e. Communication, trust and conflict resolution skills, so that the team can function effectively.

f. Team reflection, teams periodically assess what they have learned, how well they are working. Together and how they might do better as a learning team.

A research by D'Olivares (2013, p. 62) concluded that cooperative learning improves academic performance among high and low achieving students. These benefits were demonstrated by ninth graders, who were used to work against each other to get a high grade that one or a few of them could attain, this attitude started to change because students comprehended that it was not a competition, then positive effects emerged from themselves: self-esteem, social relations and constructive attitudes toward their own English learning process.

Another research by McGroarty (1993) shows that group work benefits second language learners in three ways: 
input, interaction and contextualization of knowledge. Kagan (1994) states that when students work together the positive interdependence that develops, foster social behavior and improve ethics relations. Working together help language development as well because students have the chance to use the language for a variety of purposes. Thus, cooperation is a tool that allows people to interact and to learn in an exploring environment where students are the main characters, by means of permanent interaction between peers, student-teacher, student-student, and group work.

\section{Oral Interaction.}

The pedagogical intervention of this study was based on students' oral interaction. In order to have a clear understanding about it, some of its generalities are discussed above. According to Malamah-Thomas (1988), interaction means acting reciprocally, acting upon each other. Teacher acts upon the class, but students' reaction modifies his or her next action, and so on. Class reaction functions as an action, causing a reaction in the teacher and affecting further actions. There is a permanent pattern of reciprocal influence and adaptation.

Interaction as a reciprocal process can become a smooth process or it can be tumultuous. It can have a favorable condition when participants have the impression that they are accomplishing something of value. Interaction can become cooperative or challenging. Participants' behaviors determine how interaction unfolds.

Having a plan of action means that teacher knows what he or she wants to do in the classroom. This can help the lesson because the teacher can shape interaction in something more than just action and reaction. This plan can help to avoid conflict in the interaction and communication breaks down.

\section{Research Methodology}

This is a qualitative research study with an action research approach. Firestone (1987) and Mills (2003) define action research as "a systematic inquiry, conducted by teachers with a vested interest in the teaching and learning process or environment for the purpose of gathering information about how their particular schools operate, how they teach, and how their students learn". Parsons and Brown (2002) state that action research allows teacher to study their own classroom, their own instructional methods, their own students, their own assessment; in order to better understand them and be able to improve their quality or effectiveness. Kemmis and McTaggart (2000) state that "action research is used for referrin to teacher-initiated classroom investigation which seeks to increase the teacher's understanding of classroom practices" (p.45). 
The Participants.

As a researcher in this investigation, I am a ninth grade English teacher. This research project was carried out with rural ninth graders of a private school in Ubaté, Cundinamarca. The group consisted of eighteen students; from the beginning, they were divided into six groups of three students. Some barriers such as anxiety and shyness were detected as affecting their English learning process. For that reason, this project was focused on creating practices to provide opportunities to improve students' English oral interaction by means of cooperative learning workshops.

\section{Research Instruments.}

Regarding data collection, permanent observation was used, which involved three instruments: diary, interview and workshops. First, teacher diary helped to show information about development of activities during the workshops; it helped to record students' attitudes and their oral interaction. Second, interviews provided information about students' reactions as they participate in the development of workshops. Third, workshops showed the cycle of action research.

\section{Findings.}

Considering the data collected by means of the instruments described above, a subsequent analysis led to the identification of the following category and sub-category:

Table 1. Category and subcategory

\begin{tabular}{|l|l|l|}
\hline \multicolumn{1}{|c|}{ Question } & \multicolumn{1}{|c|}{ Category } & \multicolumn{1}{c|}{ Sub-category } \\
\hline $\begin{array}{l}\text { How does cooperative } \\
\text { learning approach reduce } \\
\text { the anxiety and shyness } \\
\text { factors in order to improve } \\
\text { the students' English oral } \\
\text { interaction at a private } \\
\text { school in Ubaté? }\end{array}$ & $\begin{array}{l}\text { English Oral interaction is } \\
\text { best achieved with your } \\
\text { classmates }\end{array}$ & Well-disposed behavior \\
& & \\
& & \\
\hline
\end{tabular}

\section{English Oral Interaction is Best} Achieved with your Classmates.

The students seemed responsible and committed with the cooperative learning activities they developed in an oral way inside their groups. That allowed students to strength their oral interaction and hence, they felt the goals had been reached. Most students agreed that it is significant to recognize others' voices to grow as integral persons. 
Table 2. Excerpts from instruments

\begin{tabular}{|l|l|}
\hline $\begin{array}{l}\text { Excerpts } \\
\text { from } \\
\text { workshops }\end{array}$ & $\begin{array}{l}\text {-"the students developed their cooperative roles inside the team, one student } \\
\text { described the picture, and another described the TV, magazine photos and the rest } \\
\text { listened to and corrected if it was necessary, and so on. Finally, the students made } \\
\text { their presentations in front of the whole group" (I Workshop research cycle, pag. } \\
\text { 30). } \\
\text {-"some students did not like the idea of acting, because they dislike performing for } \\
\text { an audience, but co-workers tried to motivate among them to achieve the goal" (II } \\
\text { Workshop research cycle, pag. 38). }\end{array}$ \\
\hline $\begin{array}{l}\text { Excerpts } \\
\text { from Diary }\end{array}$ & $\begin{array}{l}\text {-"Ellos manifestaron su agrado por el taller, lo cual nos dio a entender que los } \\
\text { estudiantes les gusta trabajar siempre y cuando haya algo novedoso para hacer en } \\
\text { aras del aprendizaje, elementos como las imágenes dela revista, el espacio extramural } \\
\text { ytrabajar en equipo ayudan al estudiante a salir de lo convencional para provocar } \\
\text { en ellos nuevas actitudes frente a sus procesos de aprendizaje" (Diario 01, pág. 33). } \\
\text {-"Los estudiantes prepararon en equipo la presentación de sus héroes, las } \\
\text { comparaciones de estos con los que se proyectaron en el video beam y, finalmente, los } \\
\text { estudiantes escribieron dos párrafos acerca de los superhéroes para ser socializados } \\
\text { con todo el grupo" (Diario 02, pág 40.). }\end{array}$ \\
\hline $\begin{array}{l}\text { Excerpts } \\
\text { from } \\
\text { interviews }\end{array}$ & $\begin{array}{l}\text { "...si uno no sabe el compañero le puede aportar mucho a uno, entonces es como } \\
\text { cooperativo, si uno no sabe le enseña el compañero y si el compañero no sabe uno le } \\
\text { enseña al compañero...". (Entrevista 01, Diana. 26"). } \\
\text { ‥la solidaridad entre compañeros, y como de que a veces he incluso hay más } \\
\text { confianza entre compañeros que con el profesor". (Entrevista 01, Diana. 49"). }\end{array}$ \\
\hline
\end{tabular}

In this way, in order to reach oral interaction, ninth graders established relationships to interact with each other in English, not just to take their turn when the teacher gave instructions. The students could express by themselves in English. Based on this research experience, oral interaction is one of the main features in the students' English learning process.

It seems that through cooperative learning workshops it was possible to make students work together learning and putting into practice oral interaction. This accomplishment was confirmed in all activities from the beginning to the end of this investigation. The development of those cooperative workshops allowed students' oral interaction by actions like constructing answers together, making questions, doing presentations, watching a short documental and talking about different issues from academic topics and themselves.

\section{Well-disposed behavior.}

The pedagogical strategy helped ninth graders to get along with classmates. It was a constructive learning process in the classroom because students did not seem to give up; they were convinced of their abilities; and they showed selfesteem and self-confidence, among 
other aspects. Throughout the next the students' voices regarding this excerpts, the reader will identify subcategory.

Table 3 Excerpts from instruments

\begin{tabular}{|l|l|}
\hline $\begin{array}{l}\text { Excerpt } \\
\text { from } \\
\text { workshops }\end{array}$ & $\begin{array}{c}- \text { "The students' reactions and their attitudes were positive concerning the } \\
\text { development of this first workshop; they showed too comfortable working in this } \\
\text { cooperative way. The environment, which they worked, was an enjoyable tool for } \\
\text { them to achieve the goal; the final presentations showed the cooperation among } \\
\text { them to work, especially their wishes to help each other to do their best about the } \\
\text { target activity". (I Workshop research cycle, pag. 33). }\end{array}$ \\
\hline $\begin{array}{l}\text { Excerpt } \\
\text { from Diary }\end{array}$ & $\begin{array}{l}\text { "Los estudiantes se sintieron motivados, porque era una forma nueva para } \\
\text { ellos de salir de lo rutinario de las clases. Ellos manifestaron su agrado por el } \\
\text { cuando haya algo novedoso para hacer en aras del aprendizaje". } \\
\text { (Diario 01, pág.33). }\end{array}$ \\
\hline $\begin{array}{l}\text { Excerpt } \\
\text { from } \\
\text { interviews }\end{array}$ & $\begin{array}{l}\text { salón... (Entrevista 01, Diana. 2"). } \\
\end{array}$ \\
\hline
\end{tabular}

Students agreed that by means of the development of the cooperative learning workshops, they could share their ideas and learn more from one another. Students also said that they had good relationships among themselves and now those relationships were better than before throughout the implementation of teams into the English classroom.

\section{Conclusions}

The use of workshops based on cooperative learning has helped to reduce anxiety and shyness in ninth graders. This proposal has promoted oral interaction inside the classroom apparently leading to participants' improvement of their speaking skills.
Those activities had to deal with oral interaction to involve students in the oral use of the English language. I consider that the role of the teacher is to be a facilitator, for that reason this is an opportunity for students focus on their own learning process developing their own strategies for autonomous learning.

This proposal has involved students when working together and has given them chances to develop not just their oral interaction, but to explore possible solutions to day-today difficult situations as well. It has been an opportunity, on one hand, to get a better understanding of students' academic weaknesses and strengths; on the other hand, motivate and help them to increase their positive attitude in 
order to reduce anxiety and shyness. A cooperative learning approach has contributed to the emergence of a pleasant and comfortable atmosphere for speaking.

It was significant to create opportunities for ninth graders to speak in the classroom. Currently, the partial conclusions of this proposal are improving the circumstances for English learning. This investigation has shown that a cooperative learning approach helps to reduce students' anxiety and shyness. Success depends less on working alone, and more on working taking into account classmates.

\section{Pedagogical Implications}

Cooperative learning has been a useful approach for both student learning processes and teaching processes. Through this investigation, teachers could take into account the implementation of a cooperative learning approach to help students to improve their English oral interaction class by class.

Likewise, the cooperative learning approach brought positive results for the target experience being described since it facilitated students' English learning process and stimulated children to express themselves freely. As an English teacher, I realized that cooperative learning helped ninth graders to improve not just their academic performance, but also to become integral persons who are able to actively participate in our current society.

\section{References}

Agnes, M. (Ed.) (1999). Webster's new world college dictionary ( $4^{\text {th }}$ Ed.). New York: Macmillan.

Brandt, F. J., and Ellsworth, N. J. (1996). Effects of cooperative learning on the academic achievement and self-steem of urban adolescents with learning disabilities. Learning Disabilities 7, 9-13.

Brown. H. D. (2007). Principles of Language learning and teaching. San Francisco State University: Pearson.

Campbell, R. L. (2006). Jean Piaget's Genetic Epistemology: Appreciation and Critique. Retrieved at http://myweb.clemson. edu/ campber/piaget.html

Dahl, B. (1996). A synthesis of different psychological learning theories? Piaget and Vygotsky.

Dimitriadis, G., and Kamberelis, G. (2006). Theory for education. New York: Routledge.

D'Olivares, D. N. (2013). Cooperative learning: another way to learn together. In: Enletawa Journal. (6), 59-72.

Firestone, W. (1987). Meaning in method. The rhetoric of quantitative and qualitative research. Educational researcher.

Fogarty, R. (1999). Architects of the intellect. Educational Leadership, 57 (3), 76-78.

Gardner, R. C. (1985). Social psychology and second language learning: The role of attitudes and motivation. London: Edward Arnold Publishers.

Gardner. R.C., and MacIntyre. P. D. (1993). On the measurement of affective variables in second language learning. Language Learning, 43, 157-194. 
Guiora, Alexander, Z., Brannon, Robert C., and Dull, Cecilia, Y. (1972). Empathy and Second Language Learning. Language Learning,22, 111-130.

Horwitz, E. K., Horwitz, M. B., and Cope, J. (1986). “Foreign language classroom anxiety". Modern Language Journal, 70, 125-136.

Horwitz, E. K. (1984). “What ESL Students Believe about Language Learning" unpublished. Paper presented at the TESOL Annual Meeting, Houston.

Hymes, D. H. (1972). “On Communicative Competence" In: J.B. Pride and J. Holmes (eds) Sociolinguistics. Selected Readings. Harmondsworth: Penguin, pp. 269-293.

Johnson, D. W., and Johnson R. T. (1995). Learning together and alone. $3^{\text {rd }}$ edition. Englewood Cliffs, New Jersey: Prentice Hall.

Kagan, S. (1994). Cooperative Learning. San Clemente, CA: Kagan Publishing. Retrieved at www.Kaganonline.com

Kemmis, S., and McTaggart, R. (2000). Participatory action research. In $\mathrm{N}$. Denzin, and Y. Lincoln (Eds.). Handbook of qualitative research (2 ${ }^{\text {nd }}$ ed., pp. 567505). Thousand Oaks, CA. Sage.

Lybeck, K. (2002). Cultural identification and second language pronunciation of americans Norway. The Modern Language Journal. 86, 174-191.

Malamah-Thomas, A. (1988). Classroom interaction. Oxford. Oxford University Press.

McGroarty, M. (1993). Cooperative Learning and second language acquisition. In D. Holt, Cooperative learning. Washington, DC. Center for Applied Linguistics and
ERIC Clearing house on Languages and Linguistics.

MacIntyre, P. D., and Gardner, R.C. (1989). Anxiety and second language learning: toward a theoretical clarification. Language Learning. 32, 251-275.

Mills, G. E. (2003). Action research: A guide for the teacher researcher. Upper Saddle River, NJ. Merrill/Prentice Hall.

Palmer, J. A. (2001). Fifty modern thinkers of education. Routledge: New York.

Parsons, R. D., and Brown, K. S. (2002). Teacher as reflective practitioner and action researcher. Belmont, CA. Wadsworth / Thomson Learning.

Piaget, J. (1959). The language and through of the child (vol. 5). Psychology Press.

Savignon, S. J. (1998). Communicative competence: Theory and classroom practice. Mc Grow-hill: New York.

Scovel, T. (1978). The effect of affect on foreign language learning: A review of anxiety research. Language Learning, 28 (1), 129-142.

Siegler, R. S., and Opfer, J. (2003). The development the numerical estimation: evidence for multiple representations of the numerical quantity. Psychological Science, 14, 27-243.

Spielberger, C. D. (1983). Manual for the state-trait anxiety inventory. Palo Alto, California: Consulting Psychological Press.

Utah Education Network, (2005). Chapter One: Young Children Growing, Thinking and learning DAP and Theorists. Morgan, UT: Utah Education Network.

Vygotsky, L. S. (1978). Mind in society: the development of higher psychological 
processes. Cambridge, MA: Harvard University Press.

Woolfolk, A. (2004). Comparing Piaget and Vygotsky. Educational Psychology. Retrieved at www. education.uiowa.edu/resources / tep/eportfolio/07p075folder/Piaget_ Vygotsky.htm 